\title{
Effects of fresh garlic extract on Candida albicans sessile cells, biofilms and biofilm associated genes, Flo-8 and Ndt80
}

\author{
Dave Aranka Thomas ${ }^{1}$, Joshua Lee Voon Kai ${ }^{1}$, Choo Sulin' ${ }^{1}$, Harinash Rao $^{2}$ and Chong Pei \\ Pei $^{1, *}$ \\ ${ }^{1}$ School of Biosciences, Taylor's University, No. 1, Jalan Taylor's, 47500 Subang Jaya, Selangor, Malaysia. \\ ${ }^{2}$ School of Medicine, Taylor's University, No. 1, Jalan Taylor's, 47500 Subang Jaya, Selangor, Malaysia. \\ *Correspondence: PeiPei.Chong@taylors.edu.my
}

Received: 1 August 2021; Revised: 13 October 2021; Accepted: 16 November 2021; Published: 20 February 2022

DOI https://doi.org/10.28916/lsmb.6.1.2022.89

\begin{abstract}
Candida-associated nosocomial infections are a persistent problem which has been steadily increasing over the years. The emergence of antimicrobial resistant strains has narrowed the spectrum of effective drugs that can be utilised and indicated the need for alternative therapeutics. Garlic is a spice often studied for its unique characteristics. Most of its antimicrobial properties have been attributed to the presence of allicin, which makes up more than $70 \%$ of thiosulfinates extracted from garlic. The present study aimed to determine the effects of fresh garlic extract (FGE) towards the expression of two major biofilm genes, Flo-8 and Ndt80 produced by $C$. albicans that enable the morphogenesis of yeast from planktonic cells to biofilm. Minimum concentration required for FGE to inhibit $C$. albicans was determined through agar well and disc diffusion assay. Effect of FGE towards preformed $C$. albicans biofilms was evaluated at $1 / 4 \times$ and $1 / 2 \times$ inhibitory concentrations of FGE and Amphotericin B, respectively by XTT assay. RNA from FGE-treated $C$. albicans was extracted, reverse transcribed and analysed by Real-Time Polymerase Chain Reaction (RT-PCR) to determine FGE effects towards the expression of Flo-8 and Ndt80. Inhibitory concentration of FGE was determined to be $100 \mathrm{mg} / \mathrm{mL}$. Both genes appeared to be upregulated in the presence of FGE with a higher upregulation noted with Flo-8 (67.34 and 30.20-folds) when compared against Ndt80 (5.55 and 1.79-folds) at $5 \mathrm{mg} / \mathrm{mL}$ and $10 \mathrm{mg} / \mathrm{mL}$, respectively. It is surmised that $C$. albicans upregulated these genes as a survival mechanism in the presence of FGE. The findings from this study indicate that FGE could inhibit $C$. albicans growth and biofilms. Further research is required to determine the minimum inhibitory concentration (MIC) through broth microdilution and to understand the mechanism behind this phenomenon before it can be utilised as a potential therapeutic to combat Candida-associated nosocomial infections.
\end{abstract}

Keywords: Fresh garlic extract; Candida albicans; biofilm and antifungal

\section{INTRODUCTION}

Garlic is a common household spice with many health benefits (Majewski, 2014) including antimicrobial properties. Its inhibitory action has been described as a result of a combined effect by several compounds such as allicin, ajoenes and diallyl disulfide (DADS) (Casella et al., 2012). A study to determine the effects of fresh garlic extract (FGE) against Candida albicans ATCC 14053 demonstrated a suppression of the hyphae production and reduced expression of the gene, SIR2 (Low et al., 2008). Allicin (diallyl thiosulfinate) is a sulfur-containing organic compound that makes up a large portion $(\sim 70 \% \mathrm{w} / \mathrm{w})$ of thiosulfinates found in garlic (Rybak et al., 2004; Salehi et al., 2019). Previous studies have indicated that allicin is a promising 
alternative therapeutic that has a lower risk of triggering resistance due to its mechanism of action (Jabar \& $\mathrm{Al}$ Mossawi, 2007).

Candida sp. particularly, C. albicans is the leading cause of nosocomial infections. This genus is a common opportunistic commensal of the human body often detected in the gastrointestinal tract, oral and vaginal tract. Its dimorphic nature contributes to its pathogenic nature as it enables this microorganism to switch from yeast to hyphal form under optimum conditions such as in immunocompromised individuals (Kim \& Sudbery, 2011). Similarly, its ability to form biofilms enable it to adhere to surfaces and withstand harsh treatments, which inevitably gives rise to resistant strains (Nobile \& Johnson, 2015).

Previous studies on the genetic mechanisms behind the biofilm formations of $C$. albicans identified six master regulators; Bcr1, Brg1, Efg1, Ndt80, Rob1 and Tec1 that are responsible for regulating the expression of over a thousand genes in matured (48 h) C. albicans biofilms by binding to their upstream intergenic regions. Three additional regulators, Flo-8, Rfx2 and Gal4 were later noted to be an integral part of the C. albicans transcriptional network as they were bound to at least one of the six master regulators (Fox et al., 2015). All six master regulators including Flo-8 are positive regulators that play a role in biofilm development. Interestingly, these transcriptional regulators could exert control over similar genes as the other core regulators in the network as well as genes that are unique to them, which suggest the existence of an intricate coordination system (Nobile et al., 2012). Flo-8 encodes a transcription factor that regulates hyphal development and hyphal-specific gene expression, and plays a major role in biofilm formation as its deletion led to severe disruption of every stage of biofilm formation (Fox et al., 2015) whereas, Ndt80 is a transcription factor, which was described to exert control over other 'master regulators' involved with biofilm formation (Nobile et al., 2012). This study aimed to investigate the effects exerted by FGE towards $C$. albicans growth and the two important biofilm formation genes as there have been no available data on this.

\section{MATERIALS AND METHODOLOGY Preparation of Candida albicans strain and medium}

Candida albicans ATCC 90028 was grown on 4\% Sabouraud dextrose agar (SDA) (Merck, Darmstadt, Germany) for $24 \mathrm{~h}$ at $37^{\circ} \mathrm{C}$. The strain was stored in $20 \%$ glycerol stock at $-20{ }^{\circ} \mathrm{C}$ until further use. Prior to experimental use, C. albicans was sub-cultured thrice.

\section{Fresh garlic extract preparation}

Fresh garlic extract (FGE) was prepared using the protocol described by Low et al. (2008) with some modifications. FGE was diluted with sterile, distilled water to achieve the working concentrations of $0.1 \mathrm{mg} / \mathrm{mL}$, $1 \mathrm{mg} / \mathrm{mL}, 10 \mathrm{mg} / \mathrm{mL}$, and $100 \mathrm{mg} / \mathrm{mL}$ for agar well and disc diffusion assays while $50 \mathrm{mg} / \mathrm{mL}, 100 \mathrm{mg} / \mathrm{mL}, 200$ $\mathrm{mg} / \mathrm{mL}$, and $400 \mathrm{mg} / \mathrm{mL}$ were prepared for XTT reduction assay. FGE was freshly prepared before each experiment.

\section{Identification of antifungal properties of fresh garlic extract (FGE)}

Overnight culture of $C$. albicans was resuspended in $0.85 \%$ of sterile sodium chloride (Merck, Darmstadt, Germany) to obtain an optical density of $0.1 \pm 0.02$ at $600 \mathrm{~nm}$ (Thermo Fisher, U.S.A.), which amount to approximately $1.14 \times 10^{6} \mathrm{CFU} / \mathrm{mL}$. Minimum concentration of FGE required to exert an inhibitory effect was determined by agar well and disc diffusion assays. A volume of $100 \mu \mathrm{L}$ of $C$. albicans was spread onto the surface of fresh SDA using sterile cotton swabs. Fifty microlitres of each FGE working concentrations at a final concentration of $0.1 \mathrm{mg} / \mathrm{mL}, 1 \mathrm{mg} / \mathrm{mL}, 10 \mathrm{mg} / \mathrm{mL}$, and $100 \mathrm{mg} / \mathrm{mL}$ was aliquoted into wells that measured $5 \mathrm{~mm}$ in diameter for the agar well diffusion assay.

A total of $50 \mu \mathrm{L}$ of each FGE working concentration at a final concentration of $0.1 \mathrm{mg} / \mathrm{mL}, 1 \mathrm{mg} / \mathrm{mL}, 10 \mathrm{mg} / \mathrm{mL}$, and $100 \mathrm{mg} / \mathrm{mL}$ was aliquoted onto sterile, blank discs (Sigma, St. Louis, U.S.A.) and left to dry at room temperature. The discs were transferred onto the surface of the spread plates using tweezers, aseptically. A volume of $50 \mu \mathrm{L}$ of amphotericin B (AMB) (Sigma, St. Louis, U.S.A.) at $0.25 \mu \mathrm{g} / \mathrm{mL}$ (which was the predetermined minimum inhibitory concentration (MIC) for the test C. albicans) was prepared in dimethyl sulfoxide (DMSO) (Nacalai Tesque, Kyoto, Japan) and utilised as the positive control for agar well and disc diffusion assays. Sabouraud dextrose broth (SDB) (Merck, Darmstadt, Germany) containing 1\% DMSO was utilised as the negative control. Plates for both agar well and disc diffusion assays were incubated at $37{ }^{\circ} \mathrm{C}$ for $24 \mathrm{~h}$. Each assay was conducted in triplicates.

\section{Determination of antibiofilm properties of FGE}

Effects of FGE towards $C$. albicans biofilm was determined using the protocol established by Pierce et al. (2008) with slight modifications. Overnight cultures of $C$. albicans were washed thrice with ice cold $1 \times$ PBS and prepared to $1 \times 10^{6} \mathrm{CFU} / \mathrm{mL}$ in prewarmed RPMI-1640 (Sigma St. Louis, U.S.A.). A volume of $100 \mu \mathrm{L}$ of culture was aliquoted 
into all wells except wells in one column, which were utilised for the controls before the plate was incubated statically at $37{ }^{\circ} \mathrm{C}$ for $24 \mathrm{~h}$. All wells were washed thrice with $200 \mu \mathrm{L}$ of $1 \times$ PBS prior to the addition of $100 \mu \mathrm{L}$ of respective antifungal concentrations and incubation for $24 \mathrm{~h}$ at $37^{\circ} \mathrm{C}$, statically. Wells were prewashed thrice and $100 \mu \mathrm{L}$ of prepared XTT/menadione solution were added to each well followed by incubation at $37 \stackrel{\circ}{\circ} \mathrm{C}$ for $3 \mathrm{~h}$ in the dark. Eighty microlitres of solution from each well was transferred to a fresh plate and read at $490 \mathrm{~nm}$. FGE concentrations tested were $1 / 4 \times, 1 / 2 \times, 1 \times$ and $2 \times$ inhibitory concentration $(25 \mathrm{mg} / \mathrm{mL}, 50 \mathrm{mg} / \mathrm{mL}, 100 \mathrm{mg} / \mathrm{mL}$ and $200 \mathrm{mg} / \mathrm{mL}$, respectively) as established by the agar well and disc diffusion assays. AMB at a concentration of 0.25 $\mu \mathrm{g} / \mathrm{mL}$ and SDB with $1 \%$ DMSO served as the positive and negative controls, respectively. The assay was conducted in pairs for each concentration on three separate occasions. Paired sample t-test was performed between treated and untreated samples whereby, $\mathrm{p}$-value $<0.05$ was considered significant.

\section{Evaluation of FGE effect towards gene expression of $C$. albicans biofilm-associated genes}

Candida albicans was treated with $5 \mathrm{mg} / \mathrm{mL}$ and $10 \mathrm{mg} / \mathrm{mL}$ of FGE at $37{ }^{\circ} \mathrm{C}$ for 24 h to obtain sufficient RNA for gene expression analysis. RNA extraction was performed using RNeasy Mini Kit (Qiagen, Venlo, Netherlands) according to the manufacturer's instructions with some modifications. Sterile glass beads were initially utilised to mechanically disrupt the cell wall prior to the steps provided. Reverse transcription of RNA to cDNA was performed using the One Taq RT-PCR kit (New England Biolabs, Ipswich, Massachusetts, U.S.A.) followed by RTPCR with Luna Universal One-Step RT-PCR kit (New England Biolabs, Ipswich, Massachusetts, U.S.A.) according to the manufacturer's instructions. Fold change analysis was conducted using the Livak method (Livak and Schmittgen, 2001). Each gene was analysed in triplicate. Primers utilized are as shown below (Table 1).

Table 1: Sequences of primers utilized.

\begin{tabular}{lll}
\hline Primers & Sequences & References \\
\hline Flo-8 & Forward: & Liu et al., 2015 \\
& TCATAACTACAATTATTGCTGG & \\
& Reverse: & \\
& GTTGTTGTTGTTGTTGGCTC & Generated using Primer3 \\
& Forward: & \\
& TCCCCAACCAACACCACAAC & \\
& Reverse: & Nailis et al., 2006 \\
& GCATATCGGTCCCCACACAATA & \\
\hline GAPDH & Forward: & \\
& CGGTCCATCCCACAAGGA & \\
& Reverse: & AGTGGAAGATGGGATAATGTTACCA \\
\hline
\end{tabular}

\section{RESULTS}

\section{Antifungal and antibiofilm properties of FGE}

Zones of inhibition were noted for AMB and FGE (Table 2). Findings from agar well and disc diffusion assays indicate that only FGE at $100 \mathrm{mg} / \mathrm{mL}$ could inhibit the growth of C. albicans (Figure 1).

Table 2: Diameter of zones of inhibition noted for AMB $(0.25 \mu \mathrm{g} / \mathrm{mL})$ and FGE $(100 \mathrm{mg} / \mathrm{mL})$ after $24 \mathrm{~h}$.

\begin{tabular}{lll}
\hline & \multicolumn{2}{l}{ Zone of Inhibition $(\mathrm{mm})$} \\
\cline { 2 - 3 } & Agar Well Diffusion & Disc Diffusion \\
\hline AMB & $26.0 \pm 1.0$ & $25.7 \pm 1.2$ \\
FGE & $35.0 \pm 1.0$ & $33.3 \pm 0.6$ \\
\hline
\end{tabular}

Diameters are reported in $\mathrm{mm}$ as mean \pm standard deviation.

AMB and FGE exerted inhibitory effects towards preformed $C$. albicans biofilms. The readings observed (Table 3 ) indicates that AMB and FGE were able to disrupt C. albicans biofilms at $1 / 4 \times$ inhibitory concentration. 

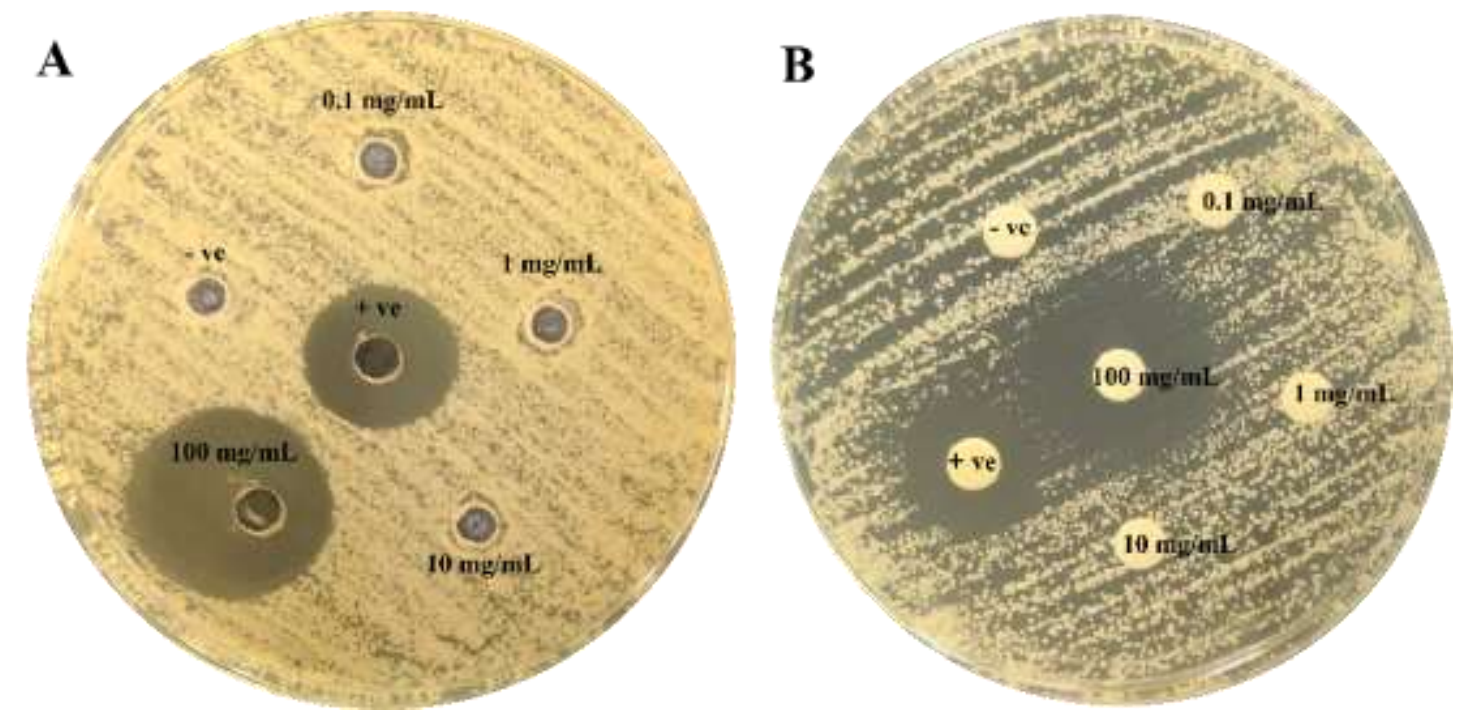

Figure 1: Anti-Candida properties exhibited by FGE through (A) agar well and (B) disc diffusion assay after $24 \mathrm{~h}$. Zones of inhibition were visible in the areas surrounding the discs and the wells of $0.25 \mathrm{ug} / \mathrm{mL}$ of $\mathrm{AMB}(+\mathrm{ve}$ control) and $100 \mathrm{mg} / \mathrm{mL}$ of FGE, respectively.

Table 3: XTT assay of $C$. albicans biofilm when treated with varying concentrations of FGE.

\begin{tabular}{lll}
\hline \multirow{2}{*}{ Concentration of antifungal agents } & \multicolumn{2}{l}{ Mean Absorbance at 490nm \pm SD using XTT assay } \\
\cline { 2 - 3 } & AMB & FGE \\
\hline Untreated cells & $0.389 \pm 0.109$ & \\
$1 / 4 \times$ inhibitory concentration & $0.053 \pm 0.015^{*}$ & $0.013 \pm 0.003^{*}$ \\
$1 / 2 \times$ inhibitory concentration & $0.038 \pm 0.009^{*}$ & $0.005 \pm 0.002^{*}$ \\
$1 \times$ inhibitory concentration & $0.012 \pm 0.005^{*}$ & $0.002 \pm 0.002^{*}$ \\
$2 \times$ inhibitory concentration & $0.002 \pm 0.001^{*}$ & $0.001 \pm 0.001^{*}$ \\
\hline
\end{tabular}

FGE; $1 / 4 \times$ inhibitory concentration $=25 \mathrm{mg} / \mathrm{mL}, 1 / 2 \times$ inhibitory concentration $=50 \mathrm{mg} / \mathrm{mL}, 1 \times$ inhibitory concentration $=100 \mathrm{mg} / \mathrm{mL}$ and $2 \times$ inhibitory concentration $=200 \mathrm{mg} / \mathrm{mL}$ and $\mathrm{AMB} ; 1 / 4 \times$ inhibitory concentration $=0.0625 \mu \mathrm{g} / \mathrm{mL}, 1 / 2 \times$ inhibitory concentration $=0.125 \mu \mathrm{g} / \mathrm{mL}, 1 \times$ inhibitory concentration $=0.25 \mu \mathrm{g} / \mathrm{mL}$ and $2 \times$ inhibitory concentration $=0.50 \mu \mathrm{g} / \mathrm{mL}$. ( $*$ indicates p-value $\leq 0.001)$

\section{Effect of FGE on the expression of $C$. albicans biofilm-associated genes}

The findings indicate an upregulation of Flo-8 (67.34 and 30.20-folds) and Ndt80 (5.55 and 1.79-folds) when treated with $5 \mathrm{mg} / \mathrm{mL}$ and $10 \mathrm{mg} / \mathrm{mL}$ of FGE, respectively. Notably, both genes showed higher fold change at 5 $\mathrm{mg} / \mathrm{mL}$ compared to $10 \mathrm{mg} / \mathrm{mL}$ (Figure 2), which indicates that this might be the optimal concentration to observe the effects exerted by FGE towards these genes. Moreover, FGE at the same concentration seems to have more effect towards the expression of Flo-8 compared to Ndt80.

\section{DISCUSSION}

C. albicans-associated nosocomial infections are a persistent problem faced by medical practitioners, particularly with the emergence of resistant strains (Savastano et al., 2016). AMB remains one of the effective antifungal drugs available (Mesa-Arango et al., 2012). It functions by binding to ergosterol, a major component in fungal membranes to cause cell death through pore formation as well as through sterol sequestration (Palacios et al., 2011). Prolonged use of this drug has been observed to cause adverse effects to its host (Laniado-Laborín \& Cabrales-Vargas, 2009). Meanwhile, garlic is one of many natural compounds that have been studied as an alternative therapeutic due to its promising antimicrobial properties with no sign of severe toxicity at higher doses (Rahman, 2007). Allicin, the major thiosulfinate extracted from garlic has been identified as the key component associated with the antimicrobial properties demonstrated by FGE (Cavallito \& Bailey, 1944). It is understood to function by inhibiting the lipid, protein and nucleic acid synthesis of microorganisms by binding to their thiol ($\mathrm{SH}$ ) groups (Fujisawa et al., 2009) but the mode of action is still not fully elucidated. Allicin has also been described to inhibit spore germination and hyphal growth (Shadkchan et al., 2004; Khodavandi et al., 2011a). 


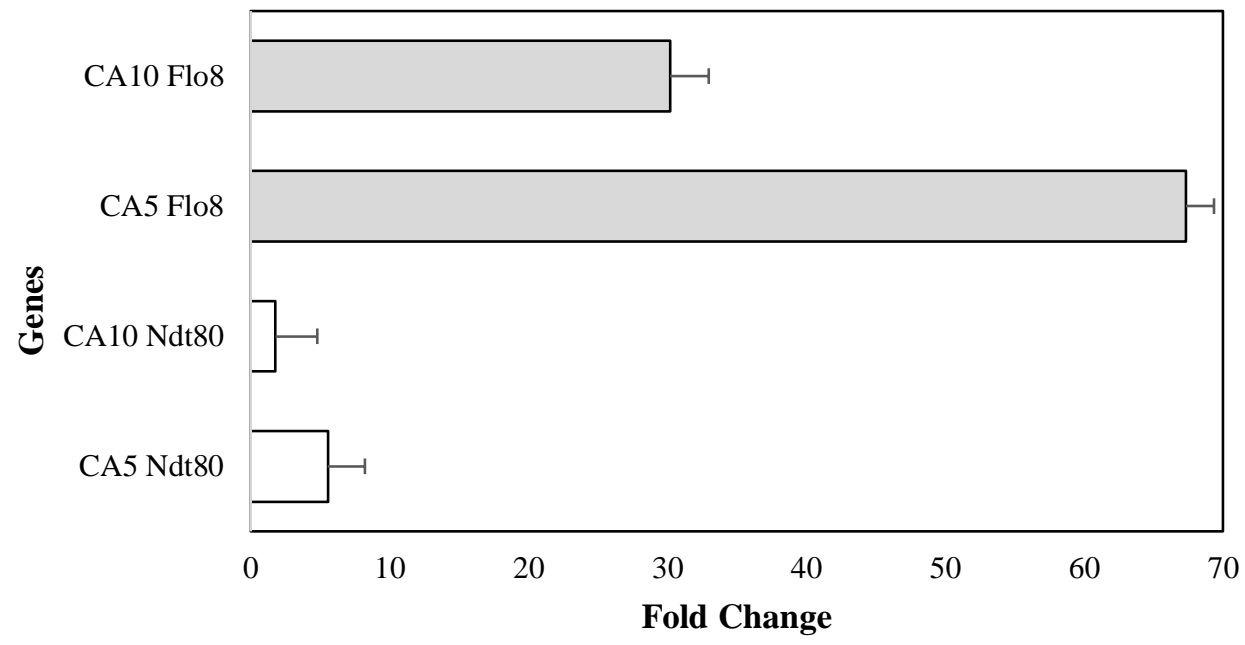

Figure 2: Fold change analysis of the expression of Flo-8 and Ndt80 after treatment with FGE (5 mg/mL and 10 $\mathrm{mg} / \mathrm{mL}$ ) derived from RT-PCR.

The present findings indicate that FGE has the ability to inhibit C. albicans at a concentration of $100 \mathrm{mg} / \mathrm{mL}$, as previously noted by Low et al. (2008). This finding is also parallel with a research by Lemar et al., (2002) in which FGE was observed to exert fungicidal effects towards $C$. albicans cells by scanning electron microscopy (SEM) and transmission electron microscopy (TEM) at $10 \mathrm{mg} / \mathrm{mL}$. Similarly, the inhibitory effects of FGE were noted in a study to compare the inhibitory effects of FGE, fluconazole and itraconazole whereby, FGE demonstrated an inhibition at $40.7 \%(\mathrm{w} / \mathrm{v})$ concentration compared to the two commercialised drugs at 15 and $8 \mu \mathrm{g} / \mathrm{mL}$, respectively (Li et al., 2015).

FGE demonstrated the ability to significantly $(\mathrm{p}<0.001)$ inhibit the metabolic activity of $C$. albicans biofilm at $1 / 4 \times$ to $2 \times$ inhibitory concentration when compared to AMB. The current findings is in support of the observations reported by Shuford et al., (2005) wherein, FGE at $4 \mathrm{mg} / \mathrm{mL}$ could effectively reduce metabolic activities at the adherence phase. An attempt to determine the effects of FGE towards the expression of the two biofilm-associated genes, Flo- 8 and Ndt80 by C. albicans demonstrated that FGE led to the increase of these genes. Flo-8 and Ndt80 are essential for invasive/filamentous switch and hyphal development as well as biofilm formation in response to stress, respectively (Fox et al., 2015). An increase in the expression of both genes in the presence of FGE could be a form of defense mechanism to protect itself from a potentially harmful environment.

Flo-8 plays a major role in every stage of biofilm development as proven through biofilm deficient mutant strains (Fox et al., 2015). Inability of $C$. albicans to form proper biofilms in the presence of FGE may have resulted in the upregulation of Flo-8 as a compensatory response in the present study. Contrary to our initial hypothesis, we postulate that the presence of FGE interfered with the progression of sessile cells to biofilm stage, which led to the overexpression of Flo-8 as the yeast cells attempt to develop into biofilms. Hence, this could indicate that the molecular target of FGE and its active constituents maybe another master regulator upstream of Flo-8 or alternatively, a pathway independent of Flo-8 altogether. Dantas et al., (2015) speculated that oxidative stress could trigger morphogenesis in C. albicans, which would also account for the upregulation of Flo-8 in the current study. A study on Candida tropicalis demonstrated that an upregulation of hyphae production resulted in an increase of several genes associated with morphological differentiation as well as oxidative response (Jiang et al., 2016). Thus, implying that the increase in Flo-8 might trigger the expression of other genes. Low and co-authors (2008) noted a downregulation of another hyphal development gene, SIR2 at $100 \mathrm{mg} / \mathrm{mL}$ of FGE with no significant inhibitory effect observed towards SAP1-4 which code for the virulence factors, secreted aspartyl proteinases. This was further justified by Khodavandi and co-workers (2011b) in their study utilising pure allicin who noted the inhibition of HWP1, a gene involved in the development of hyphal cell wall.

Ndt80 plays a role in the development of resistance under stressful conditions and in hyphal growth (Min et al., 2018). In the case of azole resistance, the overexpression of Ndt80 leads to the increase of the drug efflux pump, CDR1. Presence of FGE might have triggered a stress response in $C$. albicans that led to the increased expression of Ndt80 to pump out potential threats. Aside from that, $\mathrm{Ndt80}$ has been described to repress biofilm formation in Candida parapsilosis (Branco et al., 2021). Increase in the expression of Ndt80 in the present study could be a form of antibiofilm activity exerted by FGE. A decrease in expression of Ndt80 at $10 \mathrm{mg} / \mathrm{mL}$ demonstrates that FGE might suppress its expression alongside other virulent genes at higher concentration, hence, indicating that FGE has promising antibiofilm activities when administered before biofilms can be established at the appropriate concentrations.

One of the limitations of this study is that the effects of FGE cannot be directly compared to those of AMB as the concentration of the latter was lower at $0.25 \mu \mathrm{g} / \mathrm{mL}$. Although, previous studies have shown comparable findings between FGE or its derivatives and commercially available antifungals such as fluconazole (Khodavandi et al., 2011a), the present study does not utilise the same drug concentrations. There could be variations in the results obtained as the extraction and preparation method of FGE may vary by batch and extraction method. The 
limited range of FGE concentrations tested using RT-PCR may not be sufficient to be conclusive. Moreover, the overall effect of FGE observed in this study is a combined effect of other bioactive compounds such as ajoene, DADS, diallyl trisulfide (DATS) as well as diallyl sulfide (DAS) and should not be solely attributed to allicin.

\section{CONCLUSION}

FGE exhibited antifungal and antibiofilm effects towards $C$. albicans. The present findings indicate that FGE may trigger a response in Flo-8 and Ndt80 as evident by the upregulation of their expression at $1 / 10$ and $1 / 20 \times$ inhibitory concentration. FGE, allicin or its other derivatives exhibit promising antimicrobial properties. However, it would require more in-depth research such as determining the MIC through broth microdilution before it can be utilised as an alternative therapeutic to combat $C$. albicans-associated nosocomial infections.

\section{AUTHOR CONTRIBUTIONS}

Dave Aranka Thomas and Joshua Lee Voon Kai performed the experiments; Choo Sulin supervised the experimental conduct and wrote the manuscript, Harinash Rao supported the research and edited the manuscript. Chong Pei Pei supported, designed, supervised, edited and reviewed the manuscript. All authors read and approved the final manuscript.

\section{ETHICS APPROVAL}

No ethical approval was required as the project did not involve any human nor animal subjects.

\section{FUNDING}

The authors would like to acknowledge the Fundamental Research Grant Scheme, Malaysian Ministry of Education (FRGS/1/2019/SKK11/TAYLOR/01/1). This work was also supported by Taylor's University through its Taylor's Research Scholarship Programme.

\section{CONFLICT OF INTEREST}

The authors declare no conflicts of interest in this work.

\section{ACKNOWLEDGEMENT}

We would like to thank the Head of School of Biosciences, Associate Professor Dr. Phelim Yong for providing the budget and the facilities for this student project, and also Adillah Akhasan for help rendered in the access to the laboratory reagents and facilities.

\section{REFERENCES}

Branco, J., Martins-Cruz, C., Rodrigues, L., Silva, R. M., Araujo-Gomes, N., Goncalves, T., \& Miranda, I. M. (2021). The transcription factor of Ndt80 is a repressor of Candida parapsilosis virulence attributes. Virulence, 12(1), $601-614$. https://doi.org/10.1080/21505594.2021.1878743

Casella, S., Leonardi, M., Melai B., Fratini, F., \& Pistelli, L. (2013). The role of diallyl sulfides and dipropyl sulfides in the in vitro antimicrobial activity of the essential oil of garlic, Allium sativum L., and leek, Allium porrum L. Phytotherapy Research, 27(3), 380-383. https://doi.org/10.1002/ptr.4725

Cavallito, C. J., \& Bailey, J. B. (1944). Allicin, the antibacterial principle of Allium sativum; isolation, physical properties and antibacterial action. Journal of the American Chemical Society, 66(11), 1950-1951. https://doi.org/10.1021/ja01239a048

Dantas, A. D. S., Day, A., Ikeh, M., Kos, I., Achan, B., \& Quinn, J. (2015). Oxidative stress responses in the human fungal pathogen, Candida albicans. Biomolecules, 5(1), 142-165. https://doi.org/10.3390/biom5010142

Fox, E. P., Bui, C.K., Nett, J.E., Hartooni, N., Mui, M. C., Andes, DR, Nobile, C. J., \& Johnson, A. D. (2015). An expanded regulatory network temporally controls Candida albicans biofilm formation. Molecular Microbiology, 96(6), 1226-1239. https://doi.org/10.1111/mmi.13002 
Fujisawa, H., Watanabe, K., Suma, K., Origuchi, K., Matsufuji, H., Seki, T., \& Ariga, T. (2009). Antibacterial potential of garlicderived allicin and its cancellation by sulfhydryl compounds. Bioscience, Biotechnology and Biochemistry, 73(9), 19481955. https://doi.org/10.1271/bbb.9009

Jabar, M. A., \& Al-Mossawi, A. (2007). Susceptibility of some multiple resistant bacteria to garlic extract. African Journal of Biotechnology, 6(6), 771-776.

Jiang, C., Li, Z., Zhang, L., Tian, Y., Dong, D., \& Peng Y. (2016). Significance of hyphae formation in virulence of Candida tropicalis and transcriptomic analysis of hyphal cells. Microbiological Research, 192(2016), 65-72. https://doi.org/10.1016/i.micres.2016.06.003

Khodavandi, A., Alizadeh, F., Harmal, N. S., Sidik, S. M., Othman, F., Sekawi, Z., Jahromi, M. A. F., Ng, K. P., \& Chong, P. P. (2011a). Comparison between efficacy of allicin and fluconazole against Candida albicans in vitro and in a systemic candidiasis mouse model. FEMS Microbiology Letters, 315(2), 87-93. https://doi.org/10.1111/i.1574-6968.2010.02170.x

Khodavandi, A., Harmal, N. S., Alizadeh, F., Scully, O. J., Sidik, S. M., Othman, F., Sekawi, Z., Ng, K. P., \& Chong, P. P. (2011b). Comparison Between allicin and fluconazole in Candida albicans biofilm inhibition and In suppression of HWP1 gene expression. Phytomedicine, 19(1), 56-63. https://doi.org/10.1016/i.phymed.2011.08.060

Kim, J., \& Sudbery, P. (2011). Candida albicans, a major human fungal pathogen. Journal of Microbiology (Seoul, Korea), 49(2), 171-177. https://doi.org/10.1007/s12275-011-1064-7

Laniado-Laborín, R., \& Cabrales-Vargas, M. N. (2009). Amphotericin B: side effects and toxicity. Revista Iberoamericana de Micologia, 26(4), 223-227. https://doi.org/10.1016/i.riam.2009.06.003

Lemar, K. M., Turner, M. P., \& Lloyd, D. (2002). 'Garlic (Allium sativum) as an anti-Candida agent: A comparison of the efficacy of fresh garlic and freeze-dried extracts. Journal of Applied Microbiology, 93(3), 398-405. http://doi.org/10.1046/j.1365-2672.2002.01707.x

Li, G., Ma, X., Deng, L., Zhao, X., Wei, Y., Gao, Z., Jia, J., Xu, J., \& Sun, C. (2015). Fresh garlic extract enhances the antimicrobial activities of antibiotics on resistant strains in vitro. Jundishapur Journal of Microbiology, 8(5), e14814. https://doi.org/10.5812/ijm.14814

Liu, J. Y., Li, W. J., Shi, C., Wang, Y., Zhao, Y., \& Xiang, M. J. (2015). Mutations in the Flo8 transcription factor contribute to virulence and phenotypic traits in Candida albicans strains. Microbiological Research, 178, 1-8. https://doi.org/10/1016/i.micres.2015.05.007

Livak, K. J., Schmittgen, T. D. (2001). Analysis of relative gene expression data using real-time quantitative PCR and the 2- $\Delta \Delta \mathrm{CT}$ Method. Methods, 25, 402-408. https://doi.org/10.1006/meth.2001.1262

Low, C. F. , Chong, P. P. , Yong, P. V. C, Lim, C. S. Y., Ahmad, Z., \& Othman, F. (2008). Inhibition of hyphae formation and SIR2 expression in Candida albicans treated with fresh Allium sativum (garlic) extract. Journal of Applied Microbiology, 105(6), $2169-2177$ https://doi.org/10.1111/i.1365-2672.2008.03912.x

Majewski, M. (2014). Allium sativum: Facts and myths regarding human health. Roczniki Państwowego Zakładu Higieny, 65(1), $1-8$.

Mesa-Arango, A. C., Scorzoni, L., \& Zaragoza, O. (2012). It only takes one to do many jobs: Amphotericin B as antifungal and immunomodulatory drug. Frontiers in Microbiology, 3, 286. https://doi.org/10.3389/fmicb.2012.00286

Min, K., Biermann, A., Hogan, D. A., Konopka, J. B. (2018) Genetic analysis of NDT80) family transcription factors in Candida albicans using new CRISPR-Cas9 approaches. mSphere, 3(6), 1-13. https://doi.org/10.1128/mSphere.00545-18

Nailis, H., Coenye, T., Van Nieuwerburgh, F., Deforce, D., \& Nelis, H. J. (2006). Development and evaluation of different normalization strategies for gene expression studies in Candida albicans biofilms by real-time PCR. BMC Molecular Biology, $7,25$. https://doi.org/10.1186/1471-2199-7-25

Nobile, C. J., Fox, E. P., Nett, J. E., Sorrells, T. R., Mitrovich, Q. M., Hernday, A. D., Tuch, B. B., Andes, D. R., \& Johnson, A. D. (2012). A recently evolved transcriptional network controls biofilm development in Candida albicans. Cell, 148(1-2), 126-138. https://doi.org/10.1016/i.cell.2011.10.048

Nobile, C. J., \& Johnson, A. D. (2015). Candida albicans Biofilms and Human Disease. Annual Review of Microbiology, 69, 71-92. https://doi.org/10.1146/annurev-micro-091014-104330

Palacios, D., Dailey, I., Siebert, D., Wilcock, B., \& Burke, M. (2011). Synthesis-enabled functional group deletions reveal key underpinnings of Amphotericin B ion channel and antifungal activities. Proceedings of the National Academy of Sciences, 108(17), 6733-6738. https://doi.org/10.1073/pnas.1015023108

Pierce, C. G., Uppuluri, P., Tristan, A. R., Wormley Jr, F. L., Ramage, G., \& Lopez-Ribot, J. L. (2008). A simple and reproducible 96 well plate-based method for the formation of fungal biofilms and its application to antifungal susceptibility testing. Nature Protocols, 3(9), 1494-1500. https://doi.org/10.1038/nport.2008.141

Rahman, M. S. (2007). Allicin and other functional active components in garlic: Health benefits and bioavailability. International Journal of Food Properties, 10, 245-268. https://doi.org/10.1080/10942910601113327

Rybak, M. E., Calvey, E. M., \& Harnly, J. M. (2004). Quantitative determination of allicin in garlic: Supercritical fluid extraction and standard addition of alliin. Journal of Agricultural and Food Chemistry, 52(4), 682-687. https://doi.org/10.1021/jf034853x 
Salehi, B., Zucca, P., Orhan, I. E., Azzini, E., Adetunji, C. O., Mohammed, S. A., Banerjee, S. K., Sharopov, F., Rigano, D., SharifiRad, J., Armstrong, L., Martorell, M., Sureda, A., Martins, N., Selamoglu, Z., \& Ahmad, Z. (2019). Allicin and health: A comprehensive review. Trends in Food Sciences and Technology, 86. 502-516.

https://doi.org/10.1016/i.tifs.2019.03.003

Savastano, C., de Oliveira Silva, E., Gonçalves, L., Nery, J., Silva, N., \& Dias, A. (2016). Candida glabrata among Candida spp. from environment health practitioners of a Brazilian Hospital. Brazilian Journal of Microbiology, 47(2), 367-372. https://doi.org/10.1016/j.bjm.2015.05.001

Shadkchan, Y., Shemesh, E., Mirelman, D., Miron, T., Rabinkov, A., Wilchek, M., \& Osherov, N. (2004). Efficacy of allicin, the reactive molecule of garlic, in inhibiting Aspergillus spp. in vitro and in a murine model of disseminated aspergillosis. Journal of Antimicrobial Chemotherapy, 53(5), 832-836. https://doi.org/10.1093/jac/dkh174

Shuford, J. A., Steckelberg, J. M., \& Patel, R. (2005). Effects of fresh garlic extract on Candida albicans biofilms. Antimicrobial Agents and Chemotherapy, 49(1), 471.

https://doi.org/10.1128.AAC.49.1.473.2005

\section{Citation:}

Thomas, D. A., Lee, J. V. K., Choo, S., Rao, H., \& Chong, P. P. (2022). Effects of fresh garlic extract on Candida albicans sessile cells, biofilms and biofilm associated genes, Flo-8 and Ndt80. Life Sciences, Medicine and Biomedicine, 6(1). https://doi.org/10.28916/lsmb.6.1.2022.89

Copyright (C) 2022 by the Author(s). Life Sciences, Medicine and Biomedicine (ISSN: 2600-7207) Published by Biome Journals - Biome Scientia Sdn Bhd. Attribution 4.0 International (CC BY 4.0). This open access article is distributed based on the terms and conditions of the Creative Commons Attribution license https://creativecommons.org/licenses/by/4.0/ 